\title{
Multiplicity of Remedies in the Field of Industrial Accident Law
}

TN A FEDERAL system of government such as that of the United States of America, in which legislative and judicial authority are divided between the states and the central government, uniformity of laws is not an easy thing to obtain. Nor is nation-wide uniformity desirable in every instance. In the field of commercial law the advantages of a standardization of practice and principle are hardly open to dispute. Opinions differ, however, as to the advantages of uniformity in that branch of our jurisprudence which is concerned with the rights and remedies of workmen and their dependents for injuries or fatalities sustained in industry. One point of view is presented in the words of Mr. Justice Brandeis in his dissenting opinion in New York Cent. R. R. v. Winfield. . While intended to be applied to workmen's compensation laws, the language is applicable to other forms of relief for industrial injuries:

"The subject, of compensation for accidents in industry is one peculiarly
appropriate for state legislation. There must, necessarily, be great di-
versity in the conditions of living and in the needs of the injured and
his dependents, according to whether they reside in one or the other
of our states and territories, so widely extended. In a large majority
of instances they reside in the state in which the accident occurs. Though
the principle that compensation should be made, or relief given, is of
universal application, the great diversity of conditions in the different
sections of the United States may, in a wise application of the principle,
call for differences between states in the amount and method of coln-
pensation, the periods in which payment shall be made, and the methods
and means by which the funds shall be raised and distributed. The field
of compensation for injuries appears to be one in which uniforinity is
not desirable, or at least not essential to the public welfare." 2

However one may feel as to the desirability of mere geographical diversity such as that advocated by Mr. Justice Brandeis, and dependent upon the conditions peculiar to a given locality, there is little to say in favor of a diversity which tends to be arbitrary and capricious; which results in making a number of widely differing remedies available to employees doing similar work in the same locality; which makes the question of the applicability of a particular law depend on such irrational considerations as whether a worker at the time of the accident was standing on a deck or on a wharf, or engaged in switching an engine destined to haul freight beyond the state rather than within the state: diversity, in short, which has no clear relation either to the requirements of the community or to the vital needs of the parties

1 (1916) 244 U. S. 147. 
affected. Yet it is exactly this indefensible type of variation which is largely characteristic of our American compensation and employers' liability laws. Under the circumstances, it is inevitable that dissatisfaction and a sense of injustice will be aroused among workers who are unable to understand the legal logic which commits the family of one deceased employee to certain destitution and that of another to a reasonable degree of comfort for the rest of its dependent life.

It is possible to conceive of the happening of a single accident, confined in its effects to a radius of a few yards, and yet bringing into operation seven different sets of legal remedies, namely, the Federal Employers' Liability Act, ${ }^{3}$ the general maritime law, the Merchant Marine Act of 1920 (the Jones Act), ${ }^{4}$ the Longshoremen's and Harbor Workers' Compensation Act, ${ }^{5}$ the California Workmen's Compensation Act, ${ }^{8}$ the California Employers' Liability Act (the Roseberry Act) ${ }^{7}$ and the California wrongful death statutes. ${ }^{8}$

To illustrate: The scene is the Oakland Mole. A local train is standing upon a wharf, and the "Interstate Limited", which is just completing a run from Chicago to San Francisco, is being pushed onto an adjoining track. The leading car of the "Interstate Limited" is a United States Mail car. Moored at the end of the wharf is the train ferryboat Wilhelmina, used for transporting trains across San Francisco Bay between Oakland and San Francisco. On board the Wilhelmina, standing at the near end of the vessel upon a track which connects with that on which the Limited is approaching, is a work-car. This car is being loaded with railroad ties by stevedores and members of the Wilhelmina's crew, the ties being carried across the gangplank from the wharf to the ferryboat. The work-car contains, among other things, a quantity of dynamite to be used in road building. As the cars of the Limited move slowly down the wharf in the direction of the train-ferry, a brakeman is crushed between the local train and the car of the Limited to which he is clinging, at a point where the gradually converging tracks come so close together that there is not space enough for a man between the cars. The engineer, hearing the cry of the injured man, attempts immediately to reverse the train, but in his excitement pulls the wrong lever and the train spurts ahead toward the work-car. The engineer recovers quickly and apphes the

2 Ibid. at $168-169$.

335 STAT. (1908) 65, 45 U. S. C. (1926) §§ 51-59.

441 STAT. (1920) 1007, 46 U. S. C. (1926) \$688.

544 Stat. (1927) 1424, 33 U. S. C. SuPP. IV (1931) \$901 et seq.

6 Cal. Stats. 1917, p. 831 and subsequent amendments.

7 Cal. Stats. 1911, p. 796.

8 Cax. Code Civ. Proc. \$\$ 376, 377. 
brakes. But the brakes are not working properly, and the Limited crashes into the work-car with considerable force. The dynamite explodes, injuring a number of persons on the wharf and on the adjoining ferry-barge. The persons who thus come to grief are as follows:

$A$, a brakeman employed on the "Interstate Limited". He was upon the wharf at the time of the explosion.

$A$, the brakeman mentioned as having been crushed between the cars. He was employed regularly at the pier in switching both interstate and intrastate trains.

$B$, a diver who had been hired for a week by the railroad company to ascertain the existence of a reported subaqueous oil deposit in the vicinity of the wharf. He was on the wharf at the time of the explosion.

$C$, a member of the crew of the Wilhelmina, who was on board the vessel loading ties onto the work-car at the time of the explosion.

$D$, a stevedore employed by the railroad company. He was on board the Wilhelmina loading a tie at the time of the accident.

$E$, a stevedore employed by the railroad company. He was on the wharf about to carry a tie onto the Wilhelmina at the time of the explosion.

$F$, a government mail clerk who was at work inside the railway mail car attached to the "Interstate Limited."

To facilitate comparison of the diverse remedies nade available as a result of the accident, we shall make the somewhat fantastic assumption that each of the persons injured was totally disabled for a year, and at the end of that period, died; that each of the victims was at the time of the accident a man 35 years of age, in good health, permanently employed, and receiving a weekly wage of thirty dollars; and that each had a wife, aged 32, and two minor children, aged five and seven, wholly dependent upon him for support, and had no other persons in any way dependent upon him for pecuniary assistance. ${ }^{9}$ After the death of the breadwinner, the latter's personal representative seeks to enforce the rights of the dependent family. What are those rights?

\section{THE FEDERAI EMPIOYERS' IIABIIITY ACT}

$A$ and $\dot{A}$ are railway workers employed in interstate commerce. As such, they are members of one of the two great groups of American workers, viz., interstate railway employees and seamen, who for vari-

${ }^{9}$ Although it would be highly illuminating to compare the several pertinent systems of law from the standpoint of recovery for mjuries of varying degrees of severity, as well as for death, such a comparison will not be attempted in this article. See Armstrong, Insuring the Essentiats (1932) 652-658. 
ous reasons ${ }^{10}$ have not been afforded the protection of workmen's compensation laws. Recovery, if any, for their death, must be sought in an action at law under the provisions of the Federal Employers' Liability Act. ${ }^{11}$ The title of this Act does not indicate its scope. The word "federal" in the title merely indicates that it is enacted by Congress. The "employers" included are only interstate carriers by rail. The employees covered are only those who at the moment of injury are doing interstate commerce work for the company. It may most accurately be called "the railway-interstate-commerce workers' act." It is neither the most nor the least liberal of employer's hability laws. The basis of a right of action under the Act is the negligence of the carrier, and the burden of proving such negligence is upon the employee or those claiming under him. ${ }^{12}$ That ancient and iniquitous common law defense, the "fellow servant" doctrine, is abolished by the Act, but its brothers in infamy, the defenses of contributory negligence and assumption of risk, are abrogated only in part. The contributory negligence of the employee is no longer a complete bar to the worker's right of recovery, but serves to diminish the damages in proportion to the amount of negligence attributed by the jury to the employee. If, however, the violation by the railroad of a safety statute was a cause of the accident, contributory negligence is dispensed with entirely.13 Far more illiberal is the statute as regards assumption of risk. This doctrine survives and flourishes in all its tarnished glory, except that it may not be invoked where the violation of a safety statute contributed to the injury. In case the injury results in death, the carrier is liable in damages to the personal representative of the deceased, primarily for the benefit of the surviving widow or husband and children of the employee, and if there are none sucl, for certain other relatives. The right of action for death was construed as being

10 The chief opposition to the enactment of a compensation act for interstate railway workers has come from the Brotherhood of Railway Trainmen. This group bases its objection to such a law on the scanty benefits which are characteristic of most acts. See Doak (formerly Secretary of Labor), The Attitude of the Railroad Brotherhoods Toward Workmen's Compensation (1931) 33 MoNTr. LAB. REv. 1093. On similar grounds the International Seamen's Union of America has opposed the enactment of a compensation act for seamen. See (1928) 18 AXr. LAB. LEG. REV. 268.

1135 STAT. (1908) 65, 45 U. S. C. (1926) §§ 51-59.

12 Western Maryland Ry. v. Sanner (1917) 130 Md. 581, 101 Atl. 587, cert. dert., (1917) 245 U. S. 661 . But the defendant employer has the burden of proof on the issues of assumption of risk (Kanawha \& Michigan Ry. v. Kerse (1916) 239 U. S. 576) and contributory negligence (Central Vermont Ry. v. White (1915) 238 U. S. 507).

13 The safety statutes spoken of in the Act are federal statutes, such as the Safety Appliance Acts (45 U. S. C. (1926) $\S \S 1-46$ ) and not state statutes. Seaboard Air Line Ry. v. Horton (1914) 233 U. S. 492. 
a type of the usual "wrongful death" statute, modelled upon Lord Campbell's pioneer act, ${ }^{14}$ with the plaintiff entitled to recover in damages only the actual financial loss sustained. ${ }^{15}$ In 1910 a new section was added to the Act, whereby the right of action which was available to the employee himself was made to survive for the benefit of those claiming under the employee. ${ }^{16}$

Such, in brief, are the essential provisions of the liability act under which the bereaved dependents of the railway brakemen must seek relief. How would they fare in the light of the provisions outlined above?

The action by $A^{\prime}$ 's personal representative would be grounded on the negligence of the railroad company in failing to maintain adequate brakes upon its rolling stock. The violation of a safety statute ${ }^{17}$ having contributed to the accident, the carrier could not maintain that $A$ had assumed the risk of his employnent. ${ }^{18}$ It is, of course, impossible to estiunate with precision the damages which a jury would award to the family of $A$. The Act itself contains no directions as to the measure of damages. Nevertheless, the courts are pretty well agreed as to the elements which may enter into the claim. Remeinbering that the right of action is in the same class with the death statutes based upon Lord Campbell's Act, they assert that the recovery can be only for the actual pecuniary loss sustained..$^{10}$ Compensation for grief, loss of companionship, or other "sentimental" losses, not being translatable into financial terms, are therefore not included. ${ }^{20}$ The approved method of ascertaining pecuniary loss is to take the amount which the beneficiaries, in this case the widow and children, might reasonably have expected to receive froin the deceased, and then discount the amount, in view of the fact that ". . . a given sum of money in hand is worth inore than the like sum of money payable in the future." ${ }^{21}$ The life expectancy of the parties is a relevant factor, and mortality tables are permitted to be introduced as evidence of the same. ${ }^{22}$ Funeral expenses are not included as an element of

$149 \& 10$ VICT. (1846) c. 95.

15 Fogarty v. Northern Pacific Ry. (1915) 85 Wash. 90, 147 Pac. 652, L. R. A. $1916 \mathrm{C} 803$.

1636 STAT. (1910) 291, 45 U. S. C. (1926) $\$ 59$.

1727 STAT. (1893) 531, 45 U.S. C. (1926) \$1.

18 Union Pacific R. R. v. Huxoll (1918) 245 U. S. 535 ; Payne v. Connor (C. C.

A. 1st, 1921) 274 Fed. 497 ; 27 STAT. (1893) 532, 45 U. S. C. (1926) $\$ 7$.

19 Michigan Cent. R. R. v. Vreeland (1913) 227 U. S. 59; Chesapeake \& Ohio

Ry. v. Kelly (1916) 241 U. S. 485, Ann. Cas. 1914C 176.

20 Michigan Cent. R. R. v. Vreeland, supra note 19.

21 Chesapeake \& Ohio Ry. v. Kelly, supra note 19, at 489.

22 Philadelphia, Baltimore \& Washington R. R. v. Tucker (1910) 35 App. D. C. 123 , aff'd, (1911) 220 U. S. 608. 
damages, the explanation offered being that the liability for funeral expenses rests upon the estate, not upon the widow and children, and hence the latter cannot be said to "sustain" such a loss. ${ }^{23}$

The section added in 1910 is a departure from the usual theory of wrongful death statutes. ${ }^{24}$ As stated earlier, it professes to make the right of action of the mjured employee survive to lis personal representative for the benefit of the family. The courts are unanimous in holding that this allows the plaintiff to recover for the pain and suffering of the deceased prior to his death. ${ }^{25}$ As to other damages incurred as a result of the injury there is no such unanimity. Expenditures for medical and hospital requirements, for example, could undoubtedly have been recovered by the injured person himself, ${ }^{26}$ but apparently there is a division of authority as to whether this right survives to the personal representative. ${ }^{27}$ The plain terms of the statute would appear to sanction its survival.

If we assume $A$ to have had a life expectancy of 25 years; ${ }^{28}$ that during this period he would lave continued to earn on the average the same wage, $\$ 30.00$ per week, or $\$ 1560.00$ per year; that of this yearly sum $\$ 560.00$ may be allocated as the share spent for $A$ 's own upkeep and $\$ 1,000.00$ as the share devoted to the support of his family, including the education of his two children, we would have as the aggregate of expected pecuniary benefits $\$ 25,000.00$. Discount this at, let us say, $5 \%$ and we have $\$ 23,750.00$. To this amount add $\$ 2,500.00$ for conscious pain and suffering sustained by the deceased prior to death-not an exaggerated figure in view of the year's disability ending in death. ${ }^{29}$ To preclude the possibility of too great optimism, no allowance will be made for medical expenses during the year of incapacity ending in death. The total award will thus be $\$ 26,250.00$. That the figure arrived at is not an improbable one is indicated by an examination of the verdicts in those cases in the reports most

23 Philadelphia \& Reading Ry, v. Marland (C. C. A. 3d, 1917) 239 Fed. 1;

Delaware, L. \& W. R. R. v. Hughes (C. C. A. 2d, 1917) 240 Fed. 941.

24 36 STaT. (1910) 291, 45 U. S. C. (1926) $\$ 59$.

25 St. Louis, Iron Mt. \& Southern Ry. v. Craft (1915) 237 U. S. 648; Kansas

City Southern Ry. v. Leslie (1915) 238 U. S. 599.

20 Nashville, C. \& St. L. Ry. v. Henry (1914) 158 Ky. 88, 164 S. W. 310.

27 Allowing recovery: Berry v. St. Louis-San Francisco Ry. (1929) 324 Mo. 775, 26 S. W. (2d) 988, cert. den., (1930) 281 U. S. 765. Contra: Barnes v. Red River \& Gulf R. R. (1930) 14 La. App. 188, 128 So. 724.

28 A conservative estimate. According to the "American Experience Table of Mortality," $A$ 's expectation of life would be 31.78 years. MCLEAN, LIFE INSURANCE (3d ed. 1932) 71 .

29 See Louisville \& Nashville R. R. v. Briggs (1919) $185 \mathrm{Ky} .676,215 \mathrm{~S}$. W. 529 ; Louisville \& Nashville R. R. v. Jolly's Adm'x (1930) $232 \mathrm{Ky} .702,23 \mathrm{~S} . \mathrm{W}$. (2d) 564 , cert. den., (1930) 282 U. S. 847 , each case allowing $\$ 5,000$ for conscious pain and suffering. 
closely resembling our hypothetical situation..$^{30}$ With this sum, invested conservatively in securities paying $5 \%$ annually, the widow and children would stand in no dread of dire want.

Unfortunately for the wife and children of $\bar{A}$, the brakeman crushed between the cars, it is likely that their husband and father would be held to have assumed the risk of his employment, so far as the converging tracks are concerned. ${ }^{31}$ The risk was an obvious one, and $\dot{A}$ 's regular employment on and about the pier would negative the possibility of his not having known of the danger. Even a risk caused by the carrier's negligence, or by a breach of the common law duty to provide a "safe place to work," so long as there is no violation of a safety statute, is held to be assumed by the employee if it is fully known and appreciated by him. ${ }^{32}$

The general lay and legal public is not fully aware of the extent to which the doctrine of assumption of risk operates to defeat the recovery at law of an injured worker. In an industry such as railroading the number of risks which may be considered as "incident to the employment" is extremely high. It has been asserted that:

\footnotetext{
"Probably the work of a yard brakeman more continuously and inevitably involves risk. to life and limb than any other trade, unless it be that of an acrobat, in which risk taking is a part of the commercial end itself." 33
}

Those who are still intrepid enough to defend the doctrine do so on the grounds that an employer cannot be expected to be an insurer of the safety of his employees, and that the extra hazards incident to certain employments are compensated for by additional pay, shorter hours, and other considerations in the contract of employment. This

30 Cf. St. Louis-San Francisco Ry. v. Pearson (1926) 170 Ark. 842, 281 S. W. 910, cert. den., (1926) 273 U. S. 711 ( $\$ 30,000$ to widow and two children, deceased aged 35 , life expectancy 31 years, earning $\$ 200.00$ per month); Louisville \& Nashville $R$. R. v. Jolly's Adm'x, supra note 29 ( $\$ 33,000$ to widow and three children, including $\$ 5,000$ for conscious pain and suffering, deceased aged 31, earning about $\$ 200.00$ per month); Stottle v. Chicago, Rock Island \& Pacific Ry. (1929) $321 \mathrm{Mo}$. 1190,18 S. W. (2d) 433, cert. den., (1929) 280 U. S. 589 ( $\$ 28,000$ to widow and two children, deceased aged 27 , life expectancy 37 years, earning $\$ 180.00$ per month); Moran v. Atchison, T. \& S. F. Ry. (Mo. 1932) 48 S. W. (2d) 881, cert. den., (1932) 287 U. S. 621 ( $\$ 30,000$ to family, deceased aged 31 , life expectancy 35 years);McAdoo v. McCoy (Tex. Civ. App. 1919) 215 S. W. 870, cert. den., (1921) 255 U. S. 575 ( $\$ 25,000$ to widow and two minor children, including $\$ 5,000$ for conscious pain and suffering); Hines v. Mills (Tex. Civ. App. 1921) $218 \mathrm{~S}$. W. 777 , cert. den., (1921) 255 U. S. $576(\$ 40,000$ to wife and five children, deceased aged 38, life expectancy 29 years, earning $\$ 185.00$ per month).

31 Baugham v. New York, Philadelphia \& Norfolk R. R. (1916) 241 U. S. 237; Central Vermont Ry. v. Bethune (C. C. A. 1st, 1913) 206 Fed. 868.

32 Seaboard Air Lime Ry. v. Horton, supra note 13.

33 Eastaman, Work-accidents and the Law (N. Y. Charities Publication Committee, 1910) 18. 
belief, implying as it does a plane of bargaining equality between employer and employee, is naïve in view of conditions prevailing in the labor market. But a more fundamental criticism of the foregoing line of reasoning is that it has its origin in the discredited notion that a casualty to a worker is his own, individual affair-not the concern of society. The industrial orthodoxy of a bygone day, which regarded a man as a free agent, competent to contract in any way he saw fit, and properly burdened with whatever disastrous consequences might result from his conduct, has been supplanted by the realization that the problems of industrial injury are in a very real sense social problems, affecting not only the injured worker, but his dependent family, and, beyond the family, the community at large. Hence the almost universal acceptance of the principle of workmen's compensation, and the trend in the direction of other forms of social insurance.

However vulnerable from a social standpoint the doctrine of assumption of risk may be, it will, nevertheless, prevent a recovery by $A$ 's family under the Federal Employer's Liability Act. There is a grim irony in the fact that if $\dot{A}$ had sustained his accident under the same circumstances upon the ferry boat, he would, under the doctrine of recent cases, ${ }^{34}$ have been subject to the jurisdiction of the Longshoremen's and Harbor Workers' act, a compensation act which is not hainpered by antiquated notions in regard to "assumption of risk." Nor is the irony lessened by the realization that if $A$, whose work required him to engage indiscriminately in switching both interstate and intrastate traffic, had at the time of the accident been engaged in switching a local train, his family would have been able to obtain compensation under the state workmen's compensation act, and so been spared the prospect of poverty..$^{35}$ But since $\dot{A}$ was admittedly engaged at the time of the accident in interstate commerce, the doctrine of New York Cent. R. R. v. Winfield, ${ }^{36}$ serves to prevent his family from qualifying for relief under a state workmen's compensation act.

The Supreme Court's interpretation of the Federal Employers' Liability Act in the Winfield case has been the means of depriving the states of a field of activity which, if open to them, would have gone far to ameliorate the worst defects of the liability law. In that case it was decided that it was the intention of Congress to make negligence the sole basis of the employee's right to a remedy, and to ex-

34 Nogueira v. New York, N. H. \& H. R. R. (1930) 281 U. S. 128 ; Buren v. Southern Pacific Co. (C. C. A. 9th, 1931) 50 F. (2d) 407, cert. den., (1931) 284 U. S. 638 .

35 Armburg v. Boston \& Maine R. R. (1932) 285 U. S. 234.

36 (1916) 244 U. S. 147. 
clude responsibility of interstate carriers under state laws or otherwise for injuries not resulting from the negligence of the carrier or that of its officers, agents or other employees. As Mr. Justice Brandeis pointed out in his dissenting opinion, an equally plausible interpretation would have been that Congress intended to concern itself only with the right of recovery where the railroad was negligent, leaving the states to deal with situations not covered by the Act. There is no lack of precedent for permitting the states to exercise their reserved police powers with regard to matters affecting interstate commerce, despite the fact that Congress has legislated upon the subject. ${ }^{3 T}$ The desirability of such state legislation from the standpoint of public welfare is evident. Whether the breadwinner of a family is stricken as a result of the carrier's negligence or not, his dependent family is quite as badly in need of food, clothing, and shelter, and just as likely to become a public cliarge. In the recent case of Armburg $v$. Boston \& Maine $R . R .^{38}$ the Supreme Court expressed a view which represents some departure at least from the stand taken in the Winfield case. The question in the Armburg case was whether a state could constitutionally require a railroad engaged in both interstate and intrastate commerce to insure under the state workmen's compensation act against injuries to employees who at the time of the mjury are engaged exclusively in intrastate commerce, or else be penalized by being deprived of the defenses of fellow servant's negligence, assumption of risk, and contributory negligence $m$ an action for damages for the injury. The validity of the state law was upheld. To the argument that such legislation was improper because a burden on interstate commerce, the Supreine Court, speaking through Mr. Justice Stone, said:

\footnotetext{
"The interstate commerce clause did not withdraw from the states the power to legislate with respect to their local concerns, even though such legislation may indirectly and incidentally affect interstate commerce and persons engaged in it." 39
}

Despite the apparent trend toward greater liberality indicated by the

37 In a footnote to his dissenting opinion (n. 1, 244 U. S. at 156) Justice Brandeis cites a number of striking instances showing that ". . . Congress, in legislating upon a particular subject of interstate commerce, will not be held to have inhibited by implication the exercise by the States of their reserved police power, unless such state action would actually frustrate or impair the intended operation of the federal legislation." Cf. Sherlock v. Alling (1876) 93 U. S. 99 (state wrongful death act applied to maritime injuries); Reid v. Colorado (1902) 187 U. S. 137 (state cattle inspection laws); Asbell v. Kansas (1908) 209 U. S. 251; Savage v. Jones (1912) 225 U. S. 501 (state food labelling law); Atlantic Coast line R. R. v. Georgia (1914) 234 U. S. 280 (state locomotive headlights act); Sligh v. Kirkwood (1915) 237 U. S. 52 (state fruit quarantine act).

38 Supra note 35.

39 Ibid. at 238. 
foregoing language, it is not very likely that at this late date there will be an overruling of the Winfield case.

One of the most troublesome questions arising-and arising constantly-in connection with the Federal Employers' Liability Act is the determination of when an employee is engaged in interstate commerce, so as to bring him within the coverage of the Act. Of general formulæ there is an abundance, the most generally quoted being that laid down in Shanks v. Delaware, Lackawanna \& Western $R . R_{.40}^{40}$ to the effect that

". . . the true test of employment in such [interstate] commerce in the sense intended is, Was the employee, at the time of the injury, engaged in interstate transportation, or in work so closely related to it as to be practically a part of it?"

No useful purpose would be served by marshalling the cases and trying to deduce from them an infallible rule. ${ }^{41}$ In the first place, the decisions themselves are not altogether clear or consistent. ${ }^{22}$ In the second place, it is said that "Each case must be decided in the light of the particular facts ..." 43 It is significant that 25 years of experience with the Act liave not taught the state and inferior federal courts to determine to the satisfaction of the United States Supreme Court when an employee is and when he is not engaged in interstate commerce. One is tempted to agree heartily with the conclusion reached by Frankfurter and Landis in their analysis of the business of the United States Supreme Court at October term, 1931, in which, after reciting the disproportionately large number of cases in which the Supreme Court was obliged to deal with the liability act, and the very high percentage of reversals resulting therefrom, the authors remark:

"The deepest significance of these cases is the proof they furnish of the futility of the Act itself. When the process of interpretation and application after twenty-five years still yields unabated litigation and reveals an apparent growing inability upon the part of judges primarily entrusted with its administration to know its meaning, surely the legislation has proven a failure."

40 (1916) 239 U. S. 556, 558.

41 See on the subject "What employees are engaged in interstate commerce within the Federal Employers' Liability Act?" annotations in (1930) 65 A. L. R. 613; (1932) 77 ibid. 1374; Kennerly, The Federal Employers' Liability Act (1930) 9 TenN. L. Rev. 93.

42 See (1921) 9 CALIF. L. Rev. 260.

43 New York Cent. \& Hudson River R. R. v. Carr (1915) 238 U. S. 260, 263.

44 Frankfurter \& Landis, The Supreme Court at October Term, 1931 (1932) 46 HARv. L. REv. 226, 249. 


\section{CAIIFORNIA EMPLOYERS' IIABIITTY ACT (ROSEBERRY ACT) AND} WRONGFUL DEATH STATUTES

So much for $A$ and $A$ and the Federal Employers' Liability Act. Our attention is now to be directed to $B$, the diver who had been hired to search for an under-water oil deposit. Although employed by an interstate railway, $B$ was not doing interstate commerce work, and hence is not within the Federal Employers' Liability Act. Iikewise, he was not a "seaman," a term defined as comprising "every person (apprentices excepted) who shall be employed or engaged to serve in any capacity on board [a vessel]," 15 and so cannot assert a claim under the Jones Act. Nor does the Longshoremen's and Harbor Workers' Compensation Act, considered hereafter, apply in the present instance, since in order to come within the scope of that Act the injury must have occurred upon navigable waters. $B$ having been injured upon the pier-considered an extension of the land ${ }^{48}$ - he is therefore subject to whatever state law is applicable.

While California has enacted a workmen's compensation act, ${ }^{47}$ which is the exclusive remedy of persons who are within its operation, ${ }^{48}$ there still remain situations where the compensation act does not apply and classes of employees who are not protected by its provisions. ${ }^{40}$ In such cases section 6 (c) of the Workmen's Compensation Act provides that "the liability of the employer shall be the same as if this act had not been passed." In other words, the injured employee not within the Act, or those who seek to recover for lis death, must assert their rights, if any, in a court action predicated on the employer's negligence, under the state employers' liability act, known as the Roseberry Act, ${ }^{50}$ and the state wrongful death statutes. ${ }^{51}$ Among the workmen not covered by the Act is "any person whose employment is both casual and out of the course of the trade, business, profession or oc-

15 REv. STAT. \$4612, 46 U. S. C. (1926) \$713.

${ }^{6}$ State Industrial Comm. of New York v. Nordenholt Corp. (1922) 259 U. S. 263.

47 Cal. Stats. 1917, p. 831.

48 McLain v. Llewellyn Iron Works (1922) 56 Cal. App. 58, 204 Pac. 869; Treat v. Los Angeles Gas \& Elec. Corp. (1923) 60 Cal. App. 466, 213 Pac. 447; CaImFornia Workaren's Conipensation ACT $\$ 6$ (b).

49 Persons engaged in domestic service are one instance. Employees engaged in "farm, dairy, agricultural, viticultural, or horticultural employment or in stock or poultry raising ..." whose employers have given notice of their rejection of the Act-"contracted out"-are others. Cal. Stats. 1931, p. 1962. See Hackelberry v. Sherlock Land \& Cattle Co. (1919) 39 Cal. App. 764, 774, 180 Pac. 37, 40; Burns v. Southern Pacific Co. (1919) 43 Cal. App. 667, 672, 185 Pac. 875, 876-877 (both cases involving farm laborers).

50 Cal. Stats. 1911, p. 796; Hackelberry v. Sherlock Land \& Cattle Co.; Burns v. Southern Pacific Co., both supre note 49.

51 CaI. Code Crv. Proc. \$\$ 376, 377. 
cupation of his employer." $52 \quad B$, the diver, having been hired for only a week, and not being engaged in anything ordinarily connected with railroading, would be within the cited definition, and so not covered by the Compensation Act.

However, his personal representative would be entitled to bring suit on behalf of the widow and children against the railroad company under section 377 of the Code of Civil Procedure, which gives a right of action for death caused by the wrongful act or neglect of another. ${ }^{53}$ In this action the employer, by virtue of the Roseberry Act, could not avail himself of the common law defenses of assumption of risk or fellow servant's neghigence, while the contributory negligence of the employee would serve to diminish the damages, but not to bar the right of action. If the violation of any statute enacted for the safety of employees contributed to the employee's injury, contributory negligence could not be invoked at all. Note that in abrogating completely the doctrine of assumption of risk, the California liability act exceeds the federal act in generosity to employees.

The Cahifornia rule in regard to damages recoverable is similar to the federal rule for railway workers engaged in interstate commerce. Section 377 of the Code of Civil Procedure stipulates simply that the damages awarded shall be such as "under all the circumstances of the case may be just." Following the analogy of Lord Campbell's Act, the recovery is himited to the actual pecumary loss sustained. ${ }^{54}$ The Califorma statute differs from the federal act chiefly in not allowing the survivors to recover for the pain and suffering of the deceased before death..$^{55}$ On the other hand, the California courts have on occasion been willing to ascribe a pecuniary value to the comfort and society of the deceased spouse, ${ }^{56}$ while this is generally not permitted under the federal act. ${ }^{57}$ Medical and surgical expenses are probably not allowed as an element of damages under the state law..$^{58}$ In fixing the amount of damages suffered the courts take into consideration,

02 CaLIforma Workaten's Compensation Act \$8 (a).

53 Webster v. Norwegian Mining Co. (1902) 137 Cal. 399, 70 Pac. 276, 92 Am. St. Rep. 181; Ruiz v. Santa Barbara Gas \& Elec. Co. (1912) 164 Cal. 188, 128 Pac. 330.

54 Bond v. United Railroads (1911) 159 Cal. 270, 113 Pac. 366, 48 I. R. A. (N.s.) 687, Ann. Cas. 1912C 50; Dickinson v. Southern Pacific Co. (1916) 172 Cal. 727, 158 Pac. 183.

55 Simoneau v. Pacific Elec. Ry. (1911) 159 Cal. 494, 115 Pac. 320.

68 Beeson v. Green Mt. Gold Mining Co. (1880) 57 Cal. 20; Early v. Pacific Elec. Ry. (1917) 176 Cal. 79, 167 Pac. 513; Parsons v. Easton (1921) 184 Cal. 764, 195 Pac. 419.

57 Philadelphia \& Reading Ry. v. Marland, supra note 23; Barnes v. Red River \& Gulf R. R., supra note 27 .

6s Salmon v. Rathjens (1907) 152 Cal. 290, 92 Pac. 733. 
among other things, the wage-earning capacity of the deceased, ${ }^{60}$ and the reasonable life expectancies of the parties concerned..$^{60}$

Any estimate of the sum which a jury would award upon the facts of our hypothetical case must, of course, be highly speculative. Nevertheless, applying the rules laid down above, and assuming that throughout the period of a year the earnings of $B$ would average the same amount weekly as those of $A$; then integrating the result with the amounts granted in the most closely analogous decided cases, ${ }^{61}$ it would seem that an award of $\$ 17,000.00$ damages for the wrongful death of $B$ would be a not improbable verdict.

California's wrongful death statutes have been subjected to wellmerited criticism for their strange failure to provide for recovery by certain deserving classes of dependents. Thus, section 376 of the Code of Civil Procedure, which deals with the right of a parent to sue for the injury or death of a child, provides that the father may maintain the action, and in the event of his death or desertion, the mother. But it has been pointed out that there is no provision for suit by the mother in the event of a default by her husband other than desertion, or in those cases in which the riglit to the child's services and the obligation to support are divided between parents who are separated, or for suit by the spouse of a minor who has been emancipated by marriage. ${ }^{02}$ If the minor has no parent or guardian living, no right of action for his death is given by either code section, although the minor may leave surviving a wife, a husband, children, or brothers and sisters, who would be as substantially injured by the death as if the deceased had become of age before death ensued. ${ }^{63}$ Fortunately for the family of $B$ in our lyypothetical case, their lord and master had attained his majority before his death.

THE GENERAL MARITIME IAW AND THE JONES ACT

We turn now to the relief available to the bereaved family of $C$, who was a member of the Wilhelmina's crew, and so under the classi-

50 Peters v. Southern Pacific Co. (1911) 160 Cal. 48, 116 Pac. 400.

60 Bond v. United Railroads, supra note 54. Mortality tables may be introduced as evidence of the life expectancy. Valente v. Sierra Ry. (1910) 158 Cal. 412, 111 Pac. 95.

01 Cf. Crabbe v. Mammoth Channel Gold Miming Co. (1914) 168 Cal. 500, 143 Pac. 714 ( $\$ 20,000$ to widow and four children, deceased aged 33, life expectancy 33 years, earning between $\$ 3.50$ and $\$ 6.00$ per day); Catlin v. Union Oil Co. (1916) 31 Cal. App. 597, 161 Pac. 29 ( $\$ 17,000$ to widow and four children, ;deceased aged 44 , life expectancy 25 years, earning $\$ 2.75$ per day); Noce v. United Railroads (1923) 64 Cal. App. 658, 222 Pac. 642 ( $\$ 20,000$ to widow and two children, deceased aged 31, earning between $\$ 125.00$ and $\$ 150.00$ per month). 62 (1931) 20 Cartr. L. Rev. 95, 97.

63 For a critical discussion of sections 376 and 377 , see the opinion of Shaw, J., in Bond v. United Railroads, supra note 54. 
fication of "seaman." As such, he belonged to the second great group of workers who have not as yet been afforded the protection of a compensation act imposing upon the employer liability regardless of fault. The power to enact such a law rests with Congress, by virtue of Article 3 , section 2 of the Constitution, extending the judicial power of the United States to "all cases in admiralty and maritime jurisdiction," and Article one, section 8, the "necessary and proper" clause. Congress has not seen fit to exercise its powers in this direction. The result is that there are two sets of remedies available to a seaman injured in the course of his employment: first, the rights peculiar to the general maritime law; and second, the right of action furnished by the Jones Act, predicated upon negligence. ${ }^{64}$

Under the general maritime law a seaman was not allowed to recover damages for iujuries resulting from the neghigence of the master or any member of the crew. ${ }^{65}$ Yet in a manner anticipatory of later workmen's compensation acts, a seaman suffermg illness or injury in the service of the ship was, and is, entitled to wages, maintenance and cure, irrespective of the question of fault, and to compensation in damages from the ship, if such treatment is refused. ${ }^{66}$ Furthermore, for injuries received by seamen in consequence of the unseaworthiness of the ship or a defect in her equipment, the vessel and her owners become liable for an indemnity sounding in tort. ${ }^{67}$ Neither of the above rights survived to or vested in the heirs or personal representative of a seaman suffering death as the result of an injury received in the course of his employment. ${ }^{68}$ An exception was made in the case of death following a maritime tort committed on navigable waters within a state whose statutes gave a right of action for wrongful death.9 ${ }^{69}$ Those persons to whom the right was given were allowed to enforce it either by a suit for damages in the state courts ${ }^{70}$ or by a libel in admiralty. ${ }^{71}$

64 The acceptance by a seaman of the right to wages, maintenance and cure, kiven him by the general maritime law, is not a bar to an action for damages under the Jones Act, or to an action for indemnity for injuries resulting from the unseaworthiness of the vessel. But a seaman inust elect between the two last mentioned rights. He cannot assert both. The reason given is that the right to wages, maintenance and cure is a contractual obligation arising out of the nature of the employment, while the right to an indemnity on account of unseaworthiness and the right of action given by the Jones Act are both grounded on tort. Pacific S. S. Co. v. Peterson (1928) 278 U. S. 130.

05 The Osceola (1903) 189 U. S. 158.

$66 \mathrm{Ibid.;}$ The Iroquois (1904) 194 U. S. 240.

67 The Osceola, supra note 65 .

68 Lindgren v. United States (1930) 281 U. S. 38.

69 Western Fuel Co. v. Garcia (1921) 257 U. S. 233.

${ }^{70}$ Sherlock v. Alling (1876) 93 U. S. 99.

71 Great Lakes Dredge \& Dock Co. v. Kierejewski (1923) 261 U. S. 479. 
The Merchant Marine Act of 1920,72 known as the Jones Act, adopts the liability provisions of the Federal Employers' Liability Act, thus affording to seamen an action for damages at law based on the negligence of the master or members of the crew, with the right of trial by jury, and with the fellow servant doctrine and the defenses of contributory negligence and assumption of risk abrogated or modified as provided by the railway-interstate-commerce workers' act. But "Congress did not mean that the standards of legal duty must be the same by land and sea." 73 And so in construing such matters as what constitutes negligence under the Jones Act, the courts take into account the fact that "conditions at sea differ widely from those on land." 71 The wrongful death provisions of the Federal Employers' Liability Act are likewise imcorporated into the Jones Act, to the complete exclusion, it has been held, of state death statutes, even though the latter extend the right to different beneficiaries ${ }^{75}$ The constitutionality of the Jones Act was upheld in Panama R.R. v. Johnson $n^{76}$ over the objection that it was invalid as an attempted withdrawal of subject matter from the reach of the admiralty law. That case construed the statute as intending to permit suit under its terms to be brought either in law or in admiralty, with the state courts having jurisdiction concurrently with the federal courts. If suit is brought on the admiralty side of the federal court, the issues will be tried by the court rather than by a jury.

$C$ having been a member of the crew, mjured in the performance of maritime service on navigable waters, his personal representative would be entitled to brimg suit under the Jones Act for the benefit of $C$ 's widow and children. Since the rights of $A$ and $C$ are determined by identical acts, and since there is no valid occasion under the circumstances of the present case for differentiating between the conditions of rail and water employment, it is reasonable to suppose that the recovery of C's personal representative would be the same as $A$ 's, or approximately $\$ 26,250.00$. One grave factor which was not present in $A$ 's case may, however, operate to defeat recovery in the case of $C$, namely, the fact that suits under the Jones Act are subject to the

7241 STAT. (1920) 1007, 46 U. S. C. (1926) $\$ 688$.

73 Cortes v. Baltimore Insular Line (Dec. 5, 1932) 287 U. S. 358, 377, holding that death resulting from a negligent omission to furnish care and cure to a seaman falling ill during a voyage is death resulting from "personal injury" within the meaning of the Jones Act, and so the personal representative of the seaman may recover damages under the Act.

74 Ibid. at 377 .

75 Limdgren v. United States, supra note 68.

76 (1924) 264 U. S. 375. 
Limited Liability Acts. ${ }^{77}$ If the vessel in the instant case were a total loss, the widow and children of $C$ might be wholly deprived of recovery, ${ }^{78}$ despite the fact that the owner was fully able to recoup his losses through insurance. ${ }^{79}$

The troublesome questions of jurisdiction precipitated as a result of the decisions in Southern Pacific Co. v. Jensen, ${ }^{80}$ Knickerbocker Ice Co. v. Stewart, ${ }^{81}$ et. al., will be dealt with later.

THE IONGSHOREMEN'S AND HARBOR WORKERS' COMPENSATION ACT

Next on the list of victims is $D$, the stevedore injured while at work on board the ferry-barge. The remedy of his family is under the Longshoremen's and Harbor Workers' Compensation Act, ${ }^{82}$ passed by Congress in 1927 in response to persistent agitation and im fulfillment of a genuine need. The terms of the Iongshoremen's Act give compensation, regardless of fault, as the exclusive remedy ${ }^{83}$ for injuries ${ }^{84}$ or death sustained by workmen engaged in maritime employment on navigable waters ${ }^{85}$ of the United States, in cases where recovery through workmen's compensation proceedings may not validly be provided by state law. Some maritime workers are excepted from the operation of the Act, namely, (1) the master and members of the crew of any vessel; ${ }^{86}$ (2) any person engaged by the inaster to load or unload or repair any small vessel under eighteen tons net; ${ }^{87}$ (3) an officer or employee of the United States or any agency thereof or of any state or foreign government or of any political subdivision thereof. No compensation is payable if the injury was occasioned solely by the intoxication of the employee or by the wilful intention of the employee to injure or kill himself or another. But there is a presumption in the absence of substantial evidence to the contrary that the injury or death was not intentional or occasioned by intoxication.

77 In re East River Towing Co. (1924) 266 U. S. 355; REv. STat. \$4286, 46 U. S. C. (1926) \$186.

78 Norwich Co. v. Wright (1872) 80 U. S. (13 Wall.) 104.

79 Butler v. Boston \& Savannah S. S. Co. (1889) 130 U. S. 527.

80 (1917) 244 U. S. 205.

81 (1920) 253 U. S. 149.

8244 STAT. (1927) 1424 et seq., 33 U. S. C. SUPP. IV (1931) §901 et seq.

8344 STAT. (1927) 1426, 33 U. S. C. SUPP. IV (1931) $\$ 905$.

84 Occupational diseases are included.

85 Navigable waters are defined as including any dry-dock. 5908.

86 At the instance of the International Seamen's Union. (1927) 68 Cong. Rec.

87 "The exclusion of persons engaged by the master to load or unload or repair any small vessel under eighteen tons net seems to have had in view the case of small vessels which from time to time require the assistance of one or two men in loading or unloading or that of a mechanic in a strange port for small repairs. The language of the act clearly indicates that the exclusion is limited to employees directly engaged by the master for the purposes named." Stumberg, Harbor Workers and Workmen's Compensation (1929) 7 TEx. L. REv. 197, 201. 
The sine qua non of recovery under the Harbor Workers' Act is that the accident occur on navigable waters and that the person involved be engaged in maritime employment. ${ }^{88}$ The largest classes of workers affected by the Act are stevedores, shipyard workers, and employees of marine materialmen. ${ }^{89}$ Trouble arises in connection with the delimiting of the legitimate sphere of state legislation-a necessary determination in view of the express provision that the Act shall apply only to cases where recovery "may not validly be provided by state law." 90 The jurisdictional puzzle thus presented will be considered hereafter.

$D$, having been injured while on board the Wilhelmina loading ties, would be within the coverage of the Harbor Workers' Act. ${ }^{91}$ The compensation provisions of the Act, insofar as they bear on the recovery of $D$ 's family for his death, are the following: ${ }^{22}$ The Act provides for the payment in regular installments to specified dependents of a certain percentage of the decedent's average weekly earnings, the percentage being adjustable in accordance with the number of dependents. For purposes of compensation the wage is to be figured as not more than $\$ 37.50$ nor less than $\$ 12.00$ per week. A widow is entitled to 35 per cent of the average weekly earnings, and for each child under 18 years of age an additional 10 per cent is added, up to a maximum of $662 / 3$ per cent of the average weekly wage of the deceased. ${ }^{93}$ No award may exceed this percentage. Thus the highest weekly amount receivable by a family would be $662 / 3$ per cent of $\$ 37.50$, or $\$ 24.33$. The total amount of compensation payable as a result of any industrial accident is $\$ 7,500.00$. There is also an allowance of not to exceed $\$ 200.00$ for the reasonable expenses of the funeral. The benefit payable to a widow ceases on her death or remarriage. In the latter event, she is given a bonus equal to two years compensation in a lump sumapparently an official dowry calculated to enhance the eligibility of industrial widows. The child's benefit terminates upon death or upon reaching the age of 18 .

What may the widow and two minor children of $D$ expect to receive? It will be recalled that as a result of the accident $D$ was totally

88 Nogueira v. New York, N. H. \& H. R. R. (1930) 281 U. S. 128.

${ }^{89}$ See Northern Coal \& Dock Co. v. Strand (1928) 278 U. S. 142; Jobn Baizley Iron Works v. Span (1930) 281 U. S. 222 ; Employers' Liability Assurance Corp. v. Cook (1930) 281 U. S. 233.

9044 STAT. (1927) 1426, 33 U. S. C. SupP. IV (1931) $\$ 903$.

01 Northern Coal \& Dock Co. v. Strand, sutpra note 89.

9244 STAT. (1927) 1430, 33 U. S. C. Supp. IV (1931) $\$ 905$.

93 If there is no widow the child receives but 15 per cent, a distressingly low figure, resulting at times in genuine hardship. See Pillshury, Administration of the Longshoremen's Act on the Pacific Coast (1929) 19 AM. LAB. LEG. REv, at 260. 
disabled for one year prior to his death. $D$ 's medical expenses during this period would be paid in full. Under the provisions of the Act in regard to total disability, there would be a payment during the period of disability of $662 / 3$ per cent of $D$ 's average weekly earnings of $\$ 30.00$. This would amount to $\$ 20.00$ per week or $\$ 1040.00$ during the year. Unfortunately, this sum must be deducted from $\$ 7,500.00$, the total amount obtainable under the Act, and so $\$ 6,460.00$ is left available as a death benefit. 35 per cent of 'the average weekly wage for the widow, plus 10 per cent for each of the minor children, would mean a total of 55 per cent of D's $\$ 30.00$ wage, or $\$ 16.50$ per week. This sum is payable theoretically until the happening of one of the contingencies set forth above, such as the fact of one or more of the children becoming 18 years of age. But as a matter of actual fact, the $\$ 6,460.00$ would be exhausted long before this-in seven years and some six months. Thereafter the widow, aged 40 , and the two children, aged 13 and 15, would have to look elsewhere for the means of existence.

THE CALIFORNIA WORKMEN'S COMPENSATTON ACT

Leaving the dependents of $D$ and their rights under the Longshoremen's Act, we next concern ourselves with another stevedore and another compensation act. The only difference in the circumstances of the two stevedores, $D$ and $E$, is that $D$ happened to be upon the ferryboat at the time of the explosion, and so was brought within the federal maritime jurisdiction and the Longshoremen's and Harbor Workers' Compensation Act, while $E$ chanced at the moment to be upon the wharf, which is considered to be an extension of the land, ${ }^{94}$ and so became subject to state law, in this case the California Workmen's Compensation Act. ${ }^{95}$ The result of this accident of location is that the maximum amount of compensation receivable by the family of $E$ is $\$ 2,500.00$ less than was available to the dependents of $D$.

The California act provides for the payment of a death benefit equal to three times the average annual earnings of the decedent, which for purposes of compensation are to be considered as not less than $\$ 333.33$ nor more than $\$ 1,999.92$. This sum is payable in installments equal to 65 per cent of the average weekly earnings of the deceased employee. Consequently, the highest weekly amount receivable by a bereaved family is $\$ 25.00$. The amount of compensation is not adjustable according to the size of the family, as is roughly true of the Harbor Workers' Act. Contrary to the almost universal rule in compensation acts, remarriage of the widow does not halt the payment of the

01 State Industrial Comm. of New York v. Nordenholt Corp. (1922) 259 U. S. 263.

95 Cal. Stats. 1917, p. 831 and subsequent amendments. 
death benefit. The most deplorable feature of the California act is its limitation of the maximum amount receivable to $\$ 5,000.00 .{ }^{.8}$ Moreover, from this maximum must be deducted whatever has been paid as a disability benefit prior to death. ${ }^{07}$ Expenses for hospital and medical services are paid im full. There is also'an award of not more than $\$ 150.00$ for funeral expenses.

The average yearly earnings of $E$ were approximately $\$ 1560.00$. Three times this sum is $\$ 4,680.00$. Subtract from this the amount paid during the year of total disability, $\$ 994.50$, (65 per cent of $E^{\prime} s$ average earnings for the year, less a "waiting period" of one week), and the ridiculously small figure of $\$ 3,685.50$ remains as "compensation" for the death of $E$. This sum, paid in weekly installments of $\$ 19.50$ (65 per cent of $E$ 's average weekly earnings) will last for about three years and a half. The widow, aged 36, will then be faced with the problem of providing for herself and her two children, aged nine and eleven, by marriage or otherwise. No doubt the widow's chances of remarrying are enhanced by virtue of the fact that remarriage does not terminate the death benefit.

\section{THE UNITED STATES EMPLOYEES' COMPENSATION ACT}

We have now examined the laws applicable to six of the seven victims of the conplicated accident imagined to have occurred at the Oakland Mole. But one employee remains to be considered, $F$, the government mail clerk injured in the explosion. His family would be entitled to relief under the United States Employees' Compensation Act. The forerunner of this act, passed by Congress in $1908,{ }^{98}$ was the pioneer workmen's compensation act of this country. The statute in its present form ${ }^{99}$ is one of the least illiberal of our compensation acts. Its death benefit provisions in particular gain by comparison with most acts, including those just considered.

The coverage of the Act extends to all civil enployees of the United States and of the Panama Railroad Company. The amount of compensation payable is an adjustable percentage of the monthly earnings of the deceased employee, such earnings to be taken as not more than $\$ 175.00$ nor less than $\$ 87.50$ per month. The widow receives 35 per cent of the foregoing, and 10 per cent is added for each child under 18. The total percentage payable may not exceed $662 / 3$ per cent. Thus the maximum amount of compensation obtainable would be $\$ 116.66$ per month, which is about $\$ 26.66$ per week. Payment of

00 Cal. Stats. 1929, pp. 425-426.

97 Ibid.

8835 Stat. (1908) 556.

9939 StaT. (1916) 742 et seq., 5 U. S. C. (1926) $\$ 751$ et seq. 
the widow's allotment ceases on her death or remarriage; that of the child terminates on death, marriage, or reaching the age of 18 , unless the child is incapable of self-support. Funeral expenses of not more than $\$ 200.00$ are allowed, plus (in the discretion of the commission) the cost of transporting the body for burial in case death occurs outside the employee's home region. The obnoxious moral judgments which operate to defeat recovery under so many of our American compensation acts ${ }^{100}$ are unfortunately present in the United States Employees Act, in that no compensation is payable where death was caused by the employee's wilful misconduct, intoxication, or intention to bring about the injury or death of himself or another. Thus far, it is apparent that the terms of the Act are almost identical with those of the Longshoremen's Act. The most noteworthy difference is in regard to the maximum of compensation obtainable: the amount which may be obtained by the family of a deceased United States employee is not subject to any limitation such as that of the Harbor Workers' Act, $\$ 7,500.00$, or of the California Workmen's Compensation Act, $\$ 5,000.00$.

The recovery available to the widow and children of $F$ would be as follows: $F$ 's medical and hospital expenses during his year of disability are paid in full. He also receives $662 / 3$ per cent of what he would have earned during the year, less a three day waiting period, a total of $\$ 1,025.00$. Then, a death benefit equal to 55 per cent of $F$ 's monthly earnings of $\$ 130.00$, or $\$ 71.50$ per month (about $\$ 16.50$ per week). ${ }^{101}$ Unless death or remarriage intervenes, this amount will continue to be paid for ten years, when the eldest child becomes 18 years of age. Thereafter, 45 per cent, or $\$ 58.50$ per month ( $\$ 13.50$ per week) until the younger child reaches the age of 18 , two years later. After that the widow continues to receive 35 per cent of her late husband's wage, or $\$ 45.50$ per month ( $\$ 10.50$ per week) until the compensation ceases on account of her death or remarriage. These awards are not distinguished for munificence, but they will at least pay for a wolf-trap to place in front of the doorstep.

\section{JURISDICTION OVER MIARITIME INJURIES}

The foregoing condensed summaries of the many diverse remedies made available as the result of a single accident should suffice to demonstrate the striking lack of unity in the field of industrial accident law.

100 See ArMstrong, Insurdig the Essentiars (1932) 253-254.

101 Benefits under the U. S. Employees' Compensation Act are figured on a monthly basis. $\$ 130.00$ per month is a close enough equivalent of $\$ 30.00$ per week. The figure is arrived at by multiplying the weekly wage by 52 (the number of weeks in the year) and dividing the total by 12 (number of months in the year). 
But the difference in the nature and extent of the relief obtainable by various injured workers is not the only factor complicating the situation. Questions of jurisdiction are present which at times give the scene the intricacy of a Chinese puzzle. We have observed in connection with the Federal Employers' Liability Act that a vast quantity of useless litigation has arisen on account of the inability of the courts to decide with accuracy whether an injured railway worker was at the moment of injury engaged in interstate commerce, and so subject to the federal law, or in intrastate commerce, and therefore within the scope of state legislation. A similar conflict is present in the field of maritime injuries, and the resulting picture is, if anything, even more confusing. We shall here attempt to trace in outline the history and present status of this problem.

Article 3, section 2 of the Federal Constitution extends the judicial power of the United States to "all cases in admiralty and maritime jurisdiction." Clearly, the basis for this delegation of powers to the central government was to make possible a single, unified system of laws which would apply unifonnly to all commerce, foreign or domestic, upon the navigable waters of the United States. The advantage of such a uniform law is apparent. To make ships and shipowners subject to the local laws of every port at which a vessel touched would be to impose a very considerable burden on interstate and foreign commerce. Jurists have differed as to whether the grant of power in Article 3, section 2 was intended to prescribe any particular code or system of laws for the governance of maritime matters. Some have insisted that the constitutional provision was supposed merely to establish jurisdiction, and not to refer to or incorporate any specific body of laws, such as the "general maritime law." 102 Nevertheless it is settled that:

"... in the absence of some controlling statute, the general maritime law, as accepted by the Federal courts, constitutes parf of our national law, applicable to matters within the admiralty and maritime jurisdiction." 103

No one hasiseriously questioned that Congress has the power to alter or amend the general maritime law by statute in any way it deems fit. This statement is subjected to an important qualification, the principle of "non-delegability," discussed below.

The grant to.the United States of power over all cases in admiralty and maritime jurisdiction was not interpreted to mean that the various states were precluded from deahing with any and all aspects of the maritime jurisdiction. Section 9 of the old Judiciary Act, ${ }^{104}$ now sec-

102 See, e.g., the dissenting opinions of Holmes, J., and Pitney, J., in Southern Pacific Co. v. Jensen, supra note 80, at 218, 223.

103 Southern Pacific Co. v. Jensen, supra note 80, at 215.

1041 STAT. (1789) 77. 
tion 24 of the Judicial Code, ${ }^{105}$ expressly recognized this power in the famous "saving clause." That section gave to the district courts of the United States "exclusive original cognizance of all civil causes of admiralty and maritime jurisdiction ... saving to suitors in all cases, the right of a common law remedy, where the common law is competent to give it." In practice, statutory modifications of the common law have been recognized as well as the "common law remedy" mentioned in the act. Thus, for years the courts have been sustaining the validity of state legislation covering pilotage fees, ${ }^{106}$ state wrongful death statutes as applied to injuries received on navigable waters, ${ }^{107}$ liens created by state laws in aid of maritime contracts, ${ }^{108}$ and other inaritime matters not in conflict with the legislation of Congress. ${ }^{109}$

In view of the long-established custom set forth above, many admiralty lawyers were surprised ${ }^{110}$ when in 1917 , in the case of Southern Pacific Co. v. Jensen, ${ }^{111}$ the Supreme Court of the United States, passing for the first time on the right of a state to extend the benefits of its workmen's compensation law to a stevedore injured upon the navigable waters of the state while in the course of his employment, decided by a divided court against the applicability of the state compensation act, and stated, per McReynolds, J., that:

". . . no such legislation is valid if it contravenes the essential purpose expressed by an act of Congress, or works material prejudice to the characteristic features of the general maritime law, or interferes with the proper harmony and uniformity of that law in its international and interstate relations." 112

A workmen's compensation law, said the court, does not come within the exception provided by the Judicial Code, simce the remedy which a compensation act gives is of a character wholly unknown to the common law.

Congress promptly set about to remedy the situation by amending the saving clause to provide expressly that the states should have the right to apply their workmen's compensation acts to maritime imju-

10542 STAT. (1922) 634, 28 U. S. C. (1926) $\$ 41$ (3).

106 Olsen v. Smith (1904) 195 U. S. 332; Anderson v. Pacific Coast S. S. Co. (1912) 225 U. S. 187.

107 Sherlock v. Alling, supra note 70; The Hamilton (1907) 207 U. S. 398.

108 The J. E. Rumbell (1893) 148 U. S. 1.

109 For an enumeration of many instances of such permissive state legislation, see the dissenting opinion of Justice Pitney in Southern Pacific Co. v. Jensen, supra note 80, at $223,244,246$.

110 See Cunningham, Is Every County Court in the United States a Court of Admiralty? (1919) 53 Axr. L. REv. 749; Dodd, Jr., The New Doctrine of the Supremacy of Admiralty over the Common Law (1921) 21 CoL. L. REv. 647.

111 Supra note 80.

112 Ibid. at 216. 
ries. ${ }^{113}$ After this amendment the question came once more before the Court in the case of Knickerbocker Ice Co. v. Stewart. ${ }^{114}$ A bargeman doing work of a maritime nature had fallen into the Hudson River and been drowned. His widow claimed under the Workmen's Compensation Act of New York and the Industrial Comunission granted her an award. Both the Appellate Division and the New York Court of Appeals affirmed it.115 The Supreme Court, through Justice McReynolds, by a five-to-four vote reversed the decision, holding the attempted amendment to section 24 of the Judicial Code unconstitutional. The grounds were that the Constitution itself made necessary a uniform federal rule for all maritime matters in which uniformity was deemed necessary to preserve the general maritime law in its interstate and international aspects, and that Congress could not delegate to the states the power to apply divergent state regulations to injuries falling within the maritime jurisdiction. To the contention that there were other examples of the delegation of legislative power by Congress to the states, in particular the Webb-Kenyon Act, ${ }_{1}^{116}$ in which Congress in effect delegated to the states certain of its powers in regard to the regulation of interstate traffic in intoxicating liquors, Justice McReynolds replied, citing Clark Distilling Co. v. Western Maryland Ry., ${ }^{117}$ that the analogy was inapplicable because of the exceptional nature of the subject matter there involved, and intimated that different considerations would apply to innocuous articles of commerce.

Congress made one inore attempt at revising the saving clause to conform to the notions of the Supreme Court in regard to uniformity. It amended section 24 of the Judicial Code to provide that "claimants for compensation for injuries to or death of persons other than the master of or members of the crew of a vessel" shall retain their "rights and remedies under the workmen's compensation law of any State, ... which rights and remedies when conferred by such law shall be exclusive." 118 It was thought that by excluding masters and members of the crews of vessels from coverage by state compensation acts, the most weighty objection to permitting state laws to apply to maritime injuries would be eliminated. But the principle of the non-delegability of maritime powers had not yet spent its force. In Washington v. Dareson ${ }^{119}$ a majority of the Supreme Court ruled

11340 STAT. (1917) 395, 28 U. S. C. (1926) $\$ 41$ (3).

114 Supra note 81.

115 (1919) 187 App. Div. 915, 173 N. Y. Supp. 924, aff'd, (1919) 226 N. Y. 302, 123 N. E. 382.

11637 STaT. (1913) 699, 27 U. S. C. SUPP. IV (1931) \$122.

117 (1916) 242 U. S. 311.

11842 StaT. (1922) 634, 28 U. S. C. (1926) \$41 (3).

110 (1924) 264 U. S. 219, 225. 
that only Congress can pass laws which affect maritime matters in "their characteristic features and essential international and interstate relations." Mr. Justice Brandeis, in a powerful dissenting opinion which has been termed "the swan song of a lost cause," 120 exposed the perilous and shaky chain of reasoning which, starting from the premise "The judicial power [of the United States] shall extend to . . . all cases of admiralty and maritime jurisdiction," ends by asserting that for a state to provide that an independent contractor doing non-maritime work, such as upholstery, on a craft moored to a dock, temporarily disabled, and normally employed within the state, interferes with the "proper harmony and uniformity of the general maritine law in its international or interstate relations." ${ }^{121}$ Indeed, in the hands of Mr. Justice McReynolds and his colleagues, the "harmony of the maritime law" appears to have acquired some of the immutability of the ancient harmony of the spheres.

The Jensen case and its successors have in great part removed the subject of compensation to employees injured on navigable waters froin the scope of state legislative action. But not altogether. It will be recalled that the language of Justice McReynolds, cited above, excluded only such state legislation as would prejudice materially the "characteristic features of the general maritime law" or interfere with the uniformity of that law in "its international and interstate relations," the necessary implication being that only Congress is empowered to pass laws which are deemed to affect these essential admiralty features. At the same time, the door was left open for a limited amount of state legislation with respect to employees injured on navigable waters where the nature of the employment makes it primarily of local significance. In subsequent cases this has developed into the so-called "local concern" doctrine, a doctrine the vagueness and generality of which have caused much confusion among the courts which have been obliged to apply it.

Applying the foregoing considerations specifically to the subject of compensation for injuries sustained im maritine einployment, we find the following situation to exist: A workman who suffers an injury on navigable waters while engaged in work bearing a direct relation to navigation and commerce is within the exclusive jurisdiction of the federal law. No state compensation act can reach him. If, however, a workman is performing work which, although maritime in character, bears only an incidental relation to navigation and commerce, and

120 Morrison, Workmen's Compensation and the Maritime Lan (1929) 38 YaLe L. J. 472, 483.

121 Ibid. at 230 et seg. 
regulation of it by state law would not "work material prejudice to any characteristic feature of the general maritime law, or interfere with the proper harmony or uniformity of that law in its international and interstate relations," 122 he is compelled to seek his remedy under state law, despite the fact that the injury occurred on waters which, territorially speaking, are within the jurisdiction of admiralty..$^{123}$

Difficulties arise in applying these vague formulae to concrete cases. It has been held that one engaged as a stevedore in loading or unloading a vessel is engaged in an employment directly concerned with navigation and commerce, and consequently, if injured on navigable waters, his exclusive remedy is that provided by federal law. ${ }^{124}$ The same has been held where the employee, injured on board ship while helping to unload her, was employed to do "any kind of work" (apparently on land), and only at rare intervals to unload ships. The court said: "The unloading of a ship is not matter of purely local concern." ${ }^{25}$ It has likewise been definitely settled by the decisions of the Supreme Court that repair inen and mechanics working on a completed vessel in navigable waters are engaged in employment directly affecting commerce and navigation, and that cases of personal injury arising out of such employment are exclusively within the federal admiralty jurisdiction. ${ }^{126}$ Note that two elements unust, in the present state of the law, concur in order that the injury be cognizable exclusively by federal law: occurrence on navigable waters, and performance of employment directly affecting navigation and commerce. Consequently, a stevedore injured on the wharf while engaged in unloading a ship is within the reach of a state workmen's compensation act.127

The leading case exemplifying the "local concern" doctrine is Grant Smith-Porter Ship Co. v. Rohde, ${ }^{128}$ which held that a state compensation act could validly apply to a carpenter, not a member of the crew, injured while at work upon an incompleted vessel, which, however, had already been launched. According to Mr. Justice McReynolds,

122 Grant Smith-Porter Ship Co. v. Rohde (1922) 257 U. S. 469, 476.

123 Sultan Ry. \& Timber Co. v. Dep't of Labor (1928) 277 U. S. 135.

124 Southern Pacific Co. v. Jensen, supra note 80; Northern Coal \& Dock Co. v. Strand, supra note 89 ; see International Stevedoring Co. v. Haverty (1926) 272 U. S. 50.

125 Employers' Liability Assurance Corp. v. Cook, supra note 89, at 236.

128 Great Lakes Dredge \& Dock Co. v. Kierejewski (1923) 261 U. S. 479 (boilermaker making repairs on scow); Gonsalves v. Morse Dry Dock \& Repair Co. (1924) 266 U. S. 171 (workman repairing plates on steamer in dry dock); Robins Dry Dock \& Repair Co. v. Dahl (1925) 266 U. S. 449 (workman falling from scaffold into hold); Messel v. Foundation Co. (1927) 274 U. S. 427 (boilermaker working on smokestack); John Baizley Iron Works v. Span, supra note 89 (workman painting engine room).

127 State Industrial Comm. of New York v. Nordenholt Corp., supra note 94. 128 Supra note 122. 
"The contract for constructing 'The Ahala' was nonmaritime, and although the incompleted structure upon which the accident occurred was lying in navigable waters, neither Rohde's general employment, nor his activities at the time, had any direct relation to navigation or commerce." 129 Later cases make it clear that it is not only injuries suffered upon navigable waters while at work under non-maritime contracts which are subject to state law, but any injuries suffered in or upon navigable waters in the course of einployment which, although maritime in character, does not directly affect navigation and coinmerce. In Miller's Indemnity Underzeriters v. Braud ${ }^{\mathbf{1 3 0}}$ a diver died of suffocation while at work in navigable waters sawing off timbers which had become a menace to navigation. Justice McReynolds stated for the Court that compensation had properly been granted under a state workman's compensation act, for the reason that the matter was "of mere local concern and its regulation by the state [would] . . . work no material prejudice to any characteristic feature of the general maritime law." 131 In Alaska Packers Ass'n v. Industrial Accident Comm. of California ${ }^{132}$ the injured man had been employed by the packers association to go to Alaska as a seaman, and after his arrival there to "do anything he was told to do." He was injured in Alaska while standing on the land endeavoring to push into navigable waters a stranded boat. The Supreme Court affirmed an award of compensation made by the Industrial Accident Commission, stating that it was not necessary to determine whether in any possible view the circumstances disclosed a cause within the admiralty jurisdiction, since the petitioner's contract of employment had contemplated work on land as well as on water and the accident had occurred on land; but in any event, added the court, the work of the petitioner was local in character and so properly subject to state law. Sultan Ry. and Timber Co. v. Dep't of Labor ${ }^{133}$ was concerned with the apphicability of a state compensation statute to workmen on navigable waters engaged in assernblimg and taking apart rafts of saw logs. It was held that "where the employment, although maritime in character, pertains to local matters, having only an incidental relation to navigation and cominerce, the rights, obligations and liabilities of the parties, as between themselves, may be regulated by local rules. ..." 134

From the examples set forth above it should be evident that the

$120 \mathrm{Ibid}$. at $475-476$.

130 (1926) 270 U. S. 59.

131 Ibid. at 64.

132 (1928) 276 U. S. 467.

133 Supra note 123.

134 Ibid. at 137. 
doctrine of "local concern" has not simplified the jurisdictional problems involved in maritime injuries. The cases reveal no definite, clearcut test of jurisdiction which will operate with anything like certainty.

The enactment by Congress of the Longshoremen's and Harbor Workers' Compensation Act ${ }^{135}$ in 1927 remedied to a large extent the lamentable absence of a compensation law for maritime workers. The coverage of the Act, however, extends only to workmen injured upon navigable waters while engaged in maritime employment, and for whom recovery may not validly be provided by state workmen's compensation acts. As is true of the "Iocal concern" doctrine, the definition of "maritime employment" involves difficulties. This brings into play, it has been said, "the entire scope of admiralty conceptions of maritime services, one of the most difficult and elusive phases of our maritime law." 136

It is regrettable that Congress was moved to adopt the rule that no recovery under the Harbor Workers' Act may be had in cases where rehef through workmen's compensation proceedings may validly be provided by state law. This is, in effect, to incorporate into the act the troublesome doctrine of "local concern." If an employee is unlucky enough to be injured through no one's actionable fault on the navigable waters of one of the few backward states which have not adopted workmen's compensation laws, the rule as phrased in the Longshoremen's Act will prevent the injured worker from obtaining any relief whatsoever. Congress might have eliminated much of the disparity in relief for injured harbor workers if it had passed a workmen's compensation act applying to longshoremen and other workmen engaged in maritime employment regardless of whether the injury takes place on land or on navigable waters. Whether Congress, in the exercise of its legislative powers over admiralty and maritime matters could constitutionally pass such a law has not yet been settled. ${ }^{137}$ But by way of

13544 STAT. (1927) 1424, 33 U. S. C. SUPP. IV (1931) $\$ 901$ et seq.

136 Stumberg, op. cit. supra note 87 , at 201, where the difficulties are discussed at length.

137 In the United States the jurisdiction of admiralty in matters of contract depends upon the subject matter, i.e., the contract must he "maritime" in character. In matters of tort, the jurisdiction depends upon the locality, i.e., the place of the tort must be waters which are subject to the admiralty jurisdiction. According to the soundest view, workmen's compensation laws are neither tortious nor contractual in nature, but act to confer a status upon the parties affected. See Brandeis, J. dissenting, in Washington v. Dawson, supra note 119, at 233; North Alaska Salmon Co. v. Pillsbury (1916) 174 Cal. 1, 162 Pac. 93; Angell, Recovery under Workmen's Compensation Acts for Injury Abroad (1928) 31 HARv. L. REv. 619, 620-621. If the contract theory of workmen's compensation prevailed, Congress would clearly have the power to pass a compensation law applicable to all injuries arising out of and in the course of maritime employment, even though the place of the accident is the land. The "status" theory, likewise, 
persuasive analogy it may be noted that the admiralty jurisdiction is considered to extend to the case of a seaman injured on land while in the ship's service. One so injured is entitled to assert the right to maintenance and cure given him by the general maritime law ${ }^{138}$-a right absolute in nature, said to be annexed by law to the contract of employment, ${ }^{139}$ and hence in its essentials identical with workmen's compensation.

In view of the fact that longshoremen and harbor workers usually reside in the locality where the accident takes place, it would seem advantageous from a social standpoint to permit state compensation acts to apply to all such workers injured in the course of their employment, regardless of whether the accident occurs on land or on navigable waters. Seamen, on the other hand, traverse a great many localities, and are advisedly made subject to a unform federal law rather than to the rules of the particular region where the injury is sustamed. Unfortunately, a distinction such as that advocated, based on the natural division imto harbor workers and seamen, was repudiated in Washington v. Daweson. ${ }^{140}$ The attainment of a degree of uniformity in this field is therefore dependent upon congressional action.

CONCLUSTON AND RECONIMENDATIONS

It will be apparent from a comparison of the various laws dealt with in the preceding pages that there is a great-at times shockingdisparity in the relief available to workers doing substantially the same work in the same locality. The remedies range from no recovery at all, as in the case of the family of the railway brakeman engaged in interstate commerce who was considered to have "assumed the ordinary and obvious risks of his employment," to the recovery of many thousands of dollars, as was true of the other brakeman, to whom "assumption of risk" could not be imputed. Some of the remedies have been seen to be in the nature of actions at law, available only where negligence is capable of being proved; others are under workmen's compensation acts, providing a fixed schedule of awards graduated according to the seriousness of the casualty. Thoughtful students of the problems of industrial injury are convinced that between the two forms of would probably permit the enactment of such a law, since the regulation of the rights and obligations of maritime employment, whether or not strictly a matter of contract, would seem to be more closely identified with the field of contract than with the field of tort. The Supreme Court of the United States has not passed squarely upon the question of the nature of workmen's compensation laws. However, in a dictum in Washington v. Dawson, supra note 119 , at 227 , the Court spoke of imjuries sustamed by a longshoreman while upon a wharf as "a matter never within the admiralty jurisdiction." Does this mean that the enactment of a compensation law covering such injuries is entirely beyond the legislative power of Congress?

1381 Benedict, Admiratix (5th ed. 1925) 41.

139 Cortes v. Baltimore Insular Line (Dec. 5, 1932) 287 U. S. 358.

140 Supra note 119. 
relief-workmen's compensation, and employers' liability laws providing for suit grounded on the employer's actionable fault-there can be but one choice, namely, in favor of the principle of workmen's compensation. ${ }^{141}$ The certainty of the recovery, the absence of delay in obtaining it, the injustice of depriving the dependents of an injured worker of all relief because of the inpossibility of proving negligence on the employer's part, or because of the vicious doctrine of assumption of risk-these and other advantages of compensation laws are too well known to require development leere. As for the employers' liability acts, the sobering truth of the matter, according to Donald Richberg, is that only the very serious injuries, or deaths, are in practice subject to suit under such acts. ${ }^{142}$ In the case of less severe injuries, the possibility of a verdict for a few hundred dollars precludes the bringing of an expensive suit. So it is that the widow and children of $A$, the railway brakeman presumed to have died as a result of the explosion on the barge, are in a paradoxical sense better off than they would have been had $A$ suffered some painful, annoying, but not extremely serious, injury instead of death.

As stated previously, absolute unifornity of relief is impossible of attainment by any means short of a constitutional amendment under our present dual system of government. But much of the inequity which characterizes the present chaos could be eliminated by the enactment of federal compensation acts for two great groups of workers: interstate railway employees and seamen. The opposition to the enactment of such compensation acts is founded chiefly upon the charge that the scale of payments under practically all existing acts is pitifully inadequate. ${ }^{143}$ It cannot be denied that the objection is a valid one. ${ }^{344}$ But the answer is that, instead of devoting themselves to blocking the passage of a compensation act, to the great detriment of thousands of injured workers for whom no recovery whatever is possible under the status quo, such objectors should demonstrate their good faith by working earnestly for the enactment of a law which will provide adequate payments. ${ }^{145}$

141 See, e.g., ArMstrong, op. cit. supra note 100, at 232, 251, 282.

142 Advantages of a Federal Compensation Act for Railway Employees (1931) 21 AN. LAB. Leg. REv. 401.

143 Doak, loc. cit. supra note 10.

144 See ArMrstrong, op. cit. supra note 100, at 279.

145 Incontestable evidence of the inadequacy of the present system is presented in a report of the Bureau of Labor Statistics showing the surprisingly small amounts actually received by seamen in suits and settlements for accidents. Many seamen do not even file claims, "indicating a lack of knowledge on the part of seamen as to their rights, or a feeling of the futility of trying to press a claim because of inexperience in these matters." Significantly enough, the amounts recovered, either by suit or settlement, are on the average less than would be obtainable were the provisions of the Longshoremen's and Harbor Workers' Compensa- 
In the case of railway. employees, a law should be drafted which will care for all employees of railroads engaged in interstate commerce, regardless of whether the employee happens at the time of the accident to be engaged in interstate or intrastate cominerce. The value of such an act is that it would abolish the vice of unequal treatment for railroad employees of equal status. The major obstacle to the enactment of a law of this type is the attitude of the Supreme Court as expressed in the first Employers' Liability Cases, ${ }^{146}$ in which the Court declared that Congress lacked the power to enact a liability law applicable to employees of interstate carriers where the work of such employees was purely intrastate in character and had no direct relation to interstate commerce. It has been pointed out that the opinion of the first Employers Liability Cases was that of a divided court; that the law there rejected was poorly drafted; and the prediction has been made that it would be possible, in view of the recent decisions of the Supreme Court, to draft a law of the desired type that would successfully pass the barrier of unconstitutionality. ${ }^{147}$ In this connection a dictum of the Supreme Court itself, in the case of Illinois Cent. $R$. $R$. v. Behrens, ${ }^{148}$ is highly persuasive:

"Considering the status of the railroad as a highway for both interstate and intrastate commerce, the interdependence of the two classes of traffic in point of movement and safety, the practical difficulty in separating or dividing the general work of the switching crew, and the nature and extent of the powers confided to Congress by the commerce clause of the Constitution, we entertain no doubt that the liability of the carrier for injuries suffered by a member of the crew in the course of its general work was subject to regulation by Congress, whether the particular service being performed at the time of the injury, isolatedly considered, was in interstate or intrastate commerce. (Citing cases.) The decision in Employers' Liability Cases . . . is not to the contrary, for the act of June 11, $1906 \ldots$ there pronounced invalid, attempted to regulate the liability of every carrier in interstate commerce, whether by railroad or otherwise, for any injury to any employé, even though his employment had no connection whatever with interstate commerce."

No such objection based on constitutionality is present in the case of seamen. It is to be hoped that the near future will see the enactment of legislation calculated to remedy the marked inadequacies which are characteristic of the laws now operative.

Bertram Edises.

SCEOOL OF JURISPRUDENCE, UNIVERSTTY OF CATIFORNIA.

tion Act apphicable to seamen. Lawyers generally handle these claims on a contingent basis. In 87 per cent of the cases in which the fee could be learned, it amounted to more than one-half of the verdict recovered. Settlements for Accidents to American Seamen (1928) 26 MoNTH. LAB. REv. 6, as abstracted in Can Workmen's Compertation Benefit Seamen? (1928) 18 AM. LAB. LEG. REv. 268. 146 (1908) 207 U. S. 463.

147 Richberg, loc. cit. suprc note 142.

148 (1914) 233 U. S. 473, 477. 